\title{
The role of Emotional Intelligence in Influencing Employee Attitudes and Behavior
}

\author{
C. Catur Widayati ${ }^{1}$, Magito $^{2}$, Agung Solihin ${ }^{3}$, P. Dian Pangesti ${ }^{4}$ \\ \{catur.widayati@mercubuana.ac.id¹, magito@mercubuana.ac.id², agung.solihin@undira.ac.id ${ }^{3}$, \\ Diantyas.pangesti@gmail.com $\left.{ }^{4}\right\}$
}

\begin{abstract}
Management Department, Faculty of Economy and Business, Universitas Mercu Buana, Jakarta, Indonesia ${ }^{1}$, Management Department, Faculty of Economy and Business, Universitas Mercu Buana, Jakarta, Indonesia ${ }^{2}$, Management Department, Faculty of Economy and Business, University Dian Nusantara, West Jakarta, Jakarta, Indonesia ${ }^{3}$, Management Department, Faculty of Economy and Business, Universitas Mercu Buana, Jakarta, Indonesia ${ }^{4}$
\end{abstract}

\begin{abstract}
This study aims to explore the role of emotional intelligence in influencing employee attitudes and behavior. Three scopes become variables of employee attitudes and behavior in this study: job stress, Organizational Citizenship Behavior (OCB), and employee performance. This study uses the Structural Equation Model (SEM) with the Smart-PLS analysis tool with a quantitative research design. The research location was carried out in the service section of the PT ISS facility. The sampling technique used nonprobability sampling with a sample size of 95 people. The results showed that emotional intelligence does not always have a significant role in employee attitudes and behavior. It only appears to have a positive effect on employees' Organizational Citizenship Behavior (OCB). Meanwhile, employee performance has no strong effect. It is precisely among the three attitudes and behaviors of employees that have a relationship to influence one another. Job stress hurts employee Organizational Citizenship Behavior (OCB) and is significant to employee performance. Meanwhile, Organizational Citizenship Behavior (OCB) has a positive and significant effect on employee performance. This is evidenced by the hypothesis testing results (t-test), which shows the independent variable's significant value. The expected implication is that increasing emotional intelligence, employee attitudes, and behavior towards the company will be better.
\end{abstract}

Keywords: Attitudes, Behavior, Employee, Emotional Intelligence

\section{Introduction}

A significant thing in a company is emotional intelligence. The running of the organisation would be influenced by tension and emotional intelligence. Since emotional intelligence is as important as intellectual intelligence, emotional intelligence affects everyday activities in the organization. Each worker is supposed to have good emotional intelligence; workers can accept, handle, and monitor themselves and the emotions of others by having good emotional intelligence. Stress can be induced by employees who are unable to handle emotional intelligence well. It is expected that good emotional intelligence would enable workers to navigate the organisation in order to achieve shared objectives.

The Organizational Citizenship Behavior (OCB) of each employee is another important factor affecting the functioning of an organization. In addition, a person contribution is Organizational Citizenship Activity (OCB) which exceeds the demands of a workplace position. The Organizational Citizenship Activity (OCB) involves different tasks, volunteering for additional 
duties, and keeping with workplace rules and procedures. The "Employees' added benefit" is demonstrated by these actions and helps as one form of constructive and substantive social conduct.

Stating that performance is a description of the level of achievement of the implementation of an activity or policy in realizing organizational goals, targets to be achieved, vision and further mission as outlined in the formulation of the company's strategic scheme [1] . Job stress, emotional intelligence, and Organizational Citizenship Behavior (OCB) can affect employee performance. When solving problems faced while doing work, employees must be able to suppress stress, control their emotional intelligence, and improve Organizational Citizenship Behavior (OCB).

This research was conducted at PT ISS Indonesia. PT ISS is a company engaged in outsourcing services. This company has committed to ensure its clients in order to be able to focus on their core business and achieve business efficiency by providing and facilitating integrated services. ISS Co. Ltd. was founded in 1901 in Copenhagen, Denmark. ISS group was founded as a Danish security company. This company then entered the cleaning service market and added services for competence, becoming one of the facility service companies.largest in the world today. ESGO, a subsidiary of Hong Kong Environmental Services, was purchased by ISS Indonesia. Facility Services (Cleaning and maintenance, support services for offices, landscaping, Integrated Pest Management, business building maintenance services, indoor air quality services, laundry room services and portable toilet services), Entry Control, Catering Service and Maintenance Service for Parking are included in the scope of ISS services. The authors only analyzed the service facilities in this report.

The phenomenon that occurs in this company is that the employees are depressed due to their daily work, for example cleaning every classroom and bathroom. Bathrooms that are cleaned in a few minutes will get dirty again, which will cause reprimands from superiors, lecturers, and students. Employee stress without being accompanied by good emotional intelligence will cause work stress, where this makes employees work not wholeheartedly and will cause laziness to work, so that employee performance does not match expectations. The absence of organizational citizenship actions, as well as (OCB) of employees can reduce cooperation within the organization that causes ineffective organizational goals.

The results of previous research on OCB have been carried out by several researchers including research conducted found that emotional intelligence has negative relationship with work stress found that emotional intelligence has positive impact on Organizational Citizenship Behavior (OCB) [2][3]. Furthermore, research conducted by [4] found that emotional intelligence has positive impact on employee performance. Research [5], as well [6] found that work stress has negative impact on Organizational Citizenship Behavior (OCB). However, these findings are inversely proportional to research conducted by [7] found that job stress has a positive impact on Organizational Citizenship Behavior (OCB).

Meanwhile, research has shown that work stress has a negative effect on the output of employees [8]. However, other findings reveal the opposite result where employees' work stress has a positive effect on the performance they produce for the company [9]. Organizational Citizenship Activity (OCB) has a positive influence on the success of workers [10] [4].

Based on the background of the problem that the authors put forward, this study's focus is to determine the role of employees' emotional intelligence, which affects the attitudes and behavior of employees in the company. Three themes of attitude and behavior that focus on the research are work stress faced by employees, employee Organizational Citizenship Behavior (OCB), and performance.

Research conducted found that Organizational Citizenship Behavior (OCB) has positive and significant effect on employee performance [4] [10]. Based on the above statement, the following hypothesis can be formulated:

H1: Emotional intelligence has negative effect on job stress 
H2: Emotional intelligence has positive effect on Organizational Citizenship Behavior (OCB)

H3: Emotional intelligence has positive effect on employee performance

H4: Job stress has positive effect on Organizational Citizenship Behavior (OCB)

H5: Job stress has positive effect on employee performance

H6: Organizational Citizenship Behavior (OCB) has positive effect on employee performance

\section{Methods}

135 individuals who served at PT ISS were the population in this study. in West Jakarta in facility service department. For this reason, the sample taken from the population must be truly representative. If the sample is not representative, it will be difficult to make conclusions from the symptoms studied. Nonprobability sampling is the sampling method used in this analysis. In this study, the researcher used the Slovin formula to determine the number of samples, with a sampling error rate of $5 \%$ in order to obtain a large sample size of 95 respondents.

Interviews were conducted using a questionnaire to determine the problems that must be studied and collect the results of these interviews, especially those related to the research objectives [20]. Meanwhile, the literature study was conducted to obtain data on theories that support research.

The Component-Based Structural Equation Model is used for data processing with the PLS Partial Least Square (Smart-PLS) version 3.0 program PLS (Partial Least Square). PLS (Partial Least Square) is a effective research approach because it is not dependent on certain assumptions, data must not be distributed normally, and the sample must not be big [21].

\section{Results and Discussion}

\subsection{Measurement assessment (outer model}

\section{a. The Results of Convergent Validity Test}

The outcome of the adjustment of the convergent validity test indicates that all the indicators in the theme met the convergent validity since they have a loading factor value greater than 0.60 .

b. The Results of Discriminant Validity Test

From the results of the collection of PLS data, it can be shown that the connection between the emotional intelligence (EI) construct and its indicators is (KE2 is 0.913 , KE3 is 0.741 , KE4 is 0.919 , KE8 is 0.694 , KE9 is 0.927 , and KE11 is 0.667 ). Compared with the association of emotional intelligence factors to other constructs. In addition, the correlation of the job stress (JS) construct with its indicators (SK1 0.684, SK2 0.851, SK3 0.827, SK4 0.790, SK5 0.616, SK6 0.677, SK7 0.818 , and SK8 0.761) indicates that the indicator of correlation is higher than the indicator of correlation with other constructs for work stress. The building correlation between Organizational Citizenship Behavior (OCB) and its indicators 3 0.811, OCB4 0.822, OCB5 0.799, OCB7 0.682, OCB9 0.756, OCB10 0.780, and OCB12 0.776) indicates that these indicators are higher than the Organizational Citizenship Behavior indicator with other constructs, as well as the correlation between employee performance (EP)constructs and their indicators 844) higher than the association of metrics of employee success with other constructs 884) higher than the association of metrics of employee success with other constructs.

Table1. AVE Test Results

\begin{tabular}{lcc}
\hline & Variable & AVE \\
\hline EI & & 0.669 \\
JS & 0.573 \\
OCB & 0.603 \\
\hline
\end{tabular}




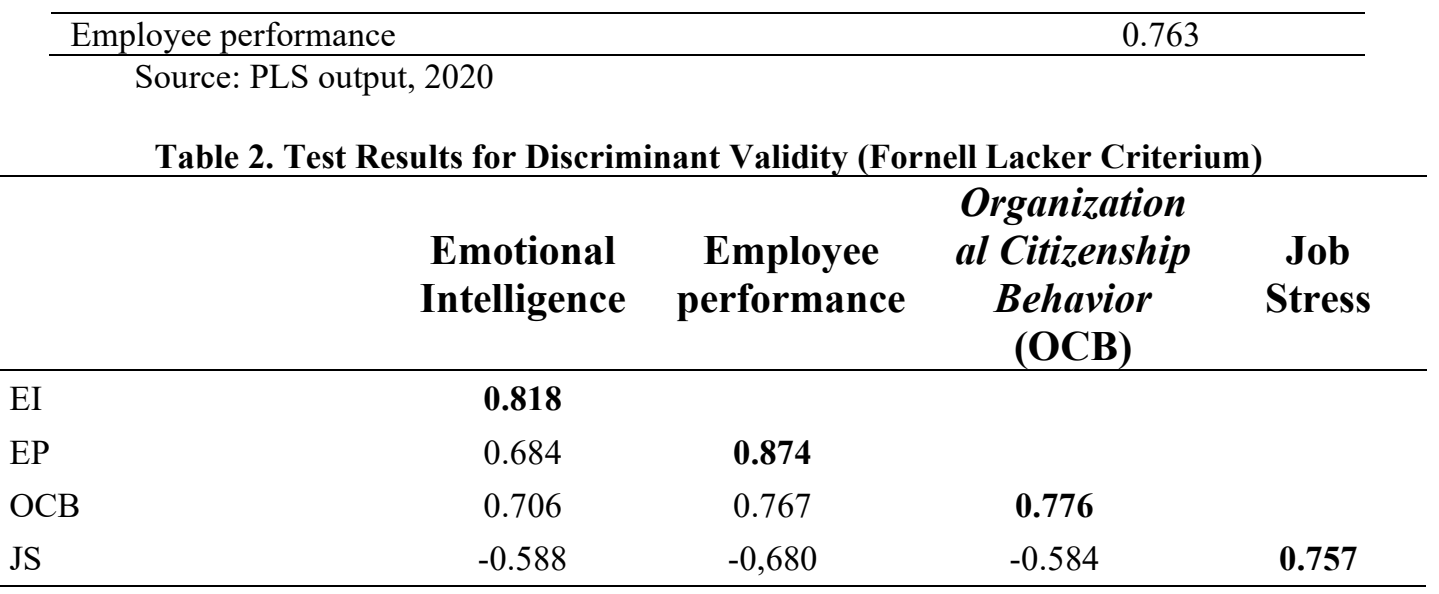

Source: PLS output, 2020

It can be inferred from Tables 1 and 2 that the square root of the average variance derived is $(\sqrt{ }(A V E))$. The relationship between one construct and the other constructs in the model is greater than one construct. The AVE value is based on the table above following the discriminant validity requirements in the estimated model.

a. The Composite Reliability Results and Alpha Test of Cronbach

In the research model, composite durability testing and Cronbach's alpha seek to assess the reliability of the tools.

Table 3. Composite Reliability Test Results

\begin{tabular}{|c|c|c|}
\hline Variable & $\begin{array}{l}\text { Composite } \\
\text { Reliability }\end{array}$ & Information \\
\hline EI & 0.922 & Reliable \\
\hline JS & 0.914 & Reliable \\
\hline $\mathrm{OCB}$ & 0.914 & Reliable \\
\hline EP & 0.951 & Reliable \\
\hline \multicolumn{3}{|c|}{ Source: PLS output, 2020} \\
\hline \multicolumn{3}{|c|}{ Table 4. The Alpha Test Findings by Cronbach } \\
\hline Variable & $\begin{array}{c}\text { Cronbach's } \\
\text { Alpha }\end{array}$ & Information \\
\hline EI & 0.896 & Reliable \\
\hline JS & 0.892 & Reliable \\
\hline $\mathrm{OCB}$ & 0890 & Reliable \\
\hline EP & 0.938 & Reliable \\
\hline
\end{tabular}

Source: PLS output, 2020

The composite reliability test results and Cronbach's alpha composite reliability values and Cronbach's alpha 0,70 are based on Table 3 and Table 4. This implies that it is claimed that all latent variables are reliable. 
For the structural model (inner model), the test steps are as follows:

a. The R-square value can be seen as follows, which is a goodness-fit model measure.

\begin{tabular}{lcc}
\multicolumn{2}{c}{ Table 5. Value $\mathbf{R}^{\mathbf{2}}$} & Endogenous Variables \\
\hline & Endogenous Variables & R-square \\
\hline JS & & 0.345 \\
OCB & 0.542 \\
EP & 0.767 \\
\hline
\end{tabular}

Source: PLS output, 2020

The structural model shows that since the value is above 0.33 , the model for the vector job stress, organizational citizenship behavior (OCB) and employee performance is moderate. Emotional Intelligence's (EI) impact model on Job Stress (JB) has an R-square value of 0.345, which means that $34.5 \%$ is the variability of the Work Stress construct, which can be clarified by the variability of the construct of Emotional Intelligence. In addition, other variables outside the one under analysis are clarified by 65.5 percent. The model of Emotional Intelligence's effect on organizational citizenship activity then gives an R-square value of 0.542 suggest that the variability of the definition of Organizational Citizenship Behavior can be explained by the 54.2 percent variability of Emotional Intelligence, while 45.8 percent can be explained by other factors. In addition, an $\mathrm{R}_{\text {square }}$ value of 0.767 is given by the model of the effect of Emotional Intelligence on Employee Performance, which means that the variability of the Employee Performance construct, which can be clarified by the variability of Emotional Intelligence, is $76.7 \%$. In contrast, excluding the one under analysis, 23.3 percent is clarified by other variables.

b. Fit Model's Goodness Results

The predictive relevance value is obtained by the formula:

$$
\begin{aligned}
Q^{2}=1-(1-R 1)\left(1-R_{p}\right) & \\
Q^{2} & =1-(1-0.345)(1-0.542)(1-0.767) \\
Q^{2} & =1-(0,655)(0,458)(0,233)
\end{aligned}
$$

$Q^{2}=1-0,0698$

$Q^{2}=0,9302$

The results of the above calculations display a value of 0.9302 of predictive significance, which is greater than 0 (zero). This implies that the independent variables used describe 93.02\% of the variance in job stress variables, Organizational Citizenship Behavior, and employee performance. Thus the model has a predictive value that is important.

c. The result of Hypothesis Test

The significance value in this hypothesis was obtained using the bootstrapping procedure.

Table 6. The Result of Hypothesis Test

\begin{tabular}{lcccl}
\hline & $\begin{array}{c}\text { Original } \\
\text { Sample }\end{array}$ & $\begin{array}{c}\text { Standard } \\
\text { Deviation }\end{array}$ & $\begin{array}{c}\boldsymbol{T} \text { - } \\
\text { Statistics }\end{array}$ & Information \\
\hline Emotional Intelligence & -0.588 & 0.069 & 8,507 & Negative - significant \\
-> Job Stress & & 0.091 & 6,099 & Positive - significant \\
Emotional Intelligence & 0.554 & 0.091 & 0.942 & Positive - \\
-> OCB & 0.086 & & & \\
Emotional Intelligence & & & &
\end{tabular}




\begin{tabular}{|c|c|c|c|c|}
\hline \multicolumn{4}{|l|}{-> Employee } & insignificant \\
\hline Performance & & & & \\
\hline $\begin{array}{l}\text { Job Stress -> OCB } \\
\text { Job Stress -> }\end{array}$ & -0.258 & 0.092 & 2,805 & Negative - significant \\
\hline $\begin{array}{l}\text { Employee } \\
\text { Performance }\end{array}$ & -0.262 & 0.067 & 3,930 & Negative - significant \\
\hline $\begin{array}{l}\text { OCB -> Employee } \\
\text { Performance }\end{array}$ & 0.629 & 0.087 & 7,246 & Positive - significant \\
\hline
\end{tabular}

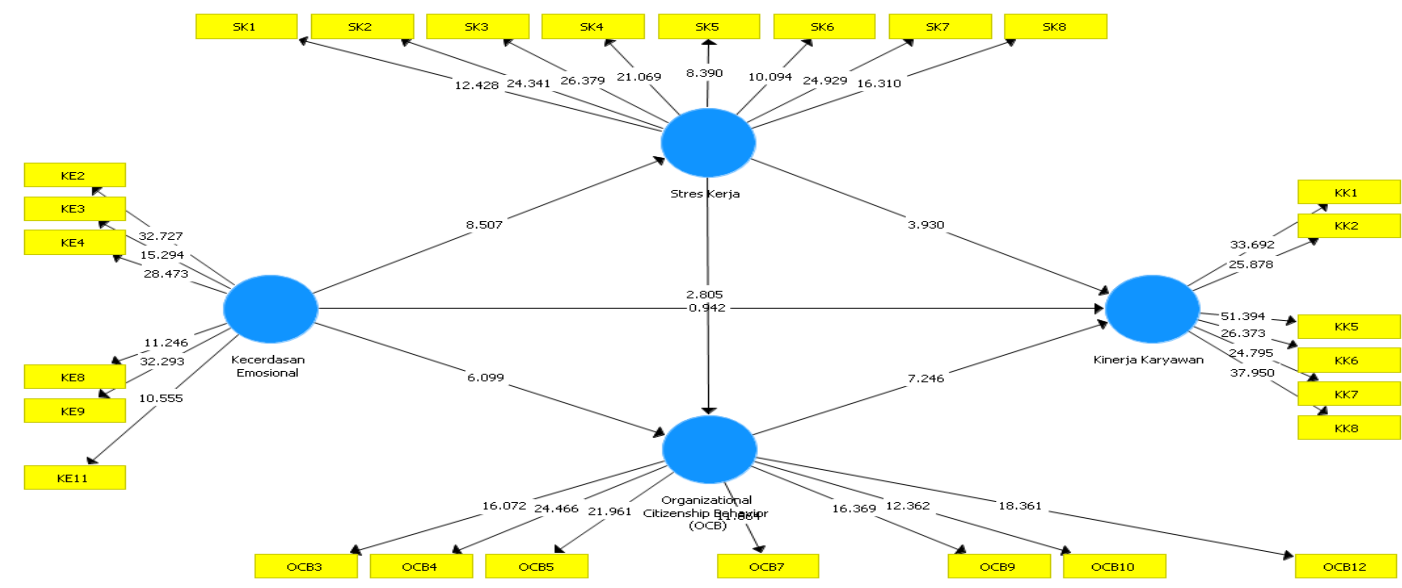

$\mathrm{F}$ igure 2. Bootstrapping Test Results Source: PLS output

\section{1) Emotional intelligence's impact on work stress}

The T-statistic value is 8.507 and the initial sample value is -0.588 depending on the outcome of the hypothesis test. The T-statistic value is higher than the $1.96 \mathrm{~T}$-table values and a negative value is demonstrated from the original sample value, which indicates that emotional intelligence has a negative and important influence on job stress. Previous research confirms the findings of this theory, showing that emotional intelligence has a negative and important influence on work stress [2]. This is in line with the phenomenon that occurs at PT ISS in West Jakarta, namely the pressures faced by employees without being accompanied by good emotional intelligence from within them will cause work stress. Employees at this company have not yet created good emotional intelligence in employees, so that work stress increases while the employee is working. From this it can be concluded that if the employee's emotional intelligence is low, the employee will be easily stressed or in other words, the employee's work stress will increase. Conversely, if the employee's emotional intelligence is high, the work stress faced by the employee will decrease.

\section{2) Impact of emotional intelligence on the actions of organizational citizenship (OCB)}

The T-statistic value is 6,099 and the initial sample value is 0.554 , based on the outcome of the hypothesis test in this analysis. The higher value of the T-statistic than T-table value of 1.96 and a positive value is demonstrated by the original sample value, which indicates that emotional intelligence has a positive and important influence on organizational citizenship behavior (OCB). The results of this hypothesis are supported by previous research which found that emotional intelligence has a positive and significant effect on Organizational Citizenship Behavior (OCB) [3]. This happens because employees are able to empathize with others and create good relationships 
among others. This can be seen from the establishment of good, harmonious relationships among employees, a healthy level of work competition, and mutual respect and respect among each other. So it can be concluded that if employees have good emotional intelligence, a good Organizational Citizenship Behavior (OCB) will be created, on the other hand, if employees do not have good emotional intelligence, a good Organizational Citizenship Behavior (OCB) will not be created.

\section{3) Effect of emotional intelligence on the output of employees}

The T-statistic value is 0.942 and the initial sample value is 0.086 , based on the outcome of the hypothesis test in this analysis. Less is the T-statistic value than the 1.96 value of the T-table. A positive value is indicated by the original sample value. This finding indicates that emotional intelligence has a positive and negligible impact on the success of employees. From these results indicate that emotional intelligence does not affect employee performance. The findings of this hypothesis vary from the research carried out that shows that emotional intelligence has a positive and important influence on the output of employees [4] [22]. The inconsistency of the research results obtained occurs because the emotional intelligence of employees who work at PT ISS in West Jakarta is relatively uncertain. The Employees who have good emotional intelligence or not, they will not affect their performance. This can happen because of the mood that employees feel at work. The result obtained indicates that emotional intelligence is not a variable that affects the level of employee performance. Good or bad performance in employees can happen even though the employee's emotional intelligence is either good or bad.

\section{4) Effect of work stress on actions of organizational citizenship (OCB)}

The T-statistic value is 2.805 and the initial sample value is -0.258 , based on the outcome of the hypothesis test in this analysis. The higher value of the T-statistic is than a negative value is seen in the T-table value of 1,96 and the initial sample value, these results indicate that work stress has a negative and significant effect on Organizational Citizenship Behavior. This is because the employees of PT ISS in West Jakarta feel boredom and are under pressure in their work and work environment. So it can be concluded that employees who are under pressure tend not doing a good Organizational Citizenship Behavior) in their work, on the other hand, if employees who do not face excessive stress are usually willing to do work outside their job descriptions or carry out Organizational Citizenship Behavior. OCB is good at his job. The findings of this hypothesis are consistent with previous studies that found that work stress has a negative impact on organizational citizenship behavior [19][6].

\section{5) The effect on employee efficiency of work stress}

The T-statistic value is 3,930 and the original sample value is $-0,262$, based on the outcome of the hypothesis test in this analysis. The T-statistic value is greater than the T-table value of 1.96 and the original sample value shows a negative value, these results indicate that work stress has a negative and significant effect onemployee performance. The findings of this hypothesis are in line with previous studies that showed that work stress has a negative effect on the performance of employees [8]. It is proven that the pressure felt by PT ISS employees in West Jakarta at work reduces their performance. Employees' high or low stress can affect their performance because the findings of this study indicate that work stress is a variable that influences employees' performance. So, the higher the work stress experienced by employees, the lower the employee's performance; on the other hand, if the lower the stress experienced by employees, the higher the employee's performance will increase. 


\section{5) The effect on employee efficiency of Organizational Citizenship Actions (OCB)}

The T-statistic value is 7.246 and the original sample value is 0.629 , based on the outcome of the hypothesis test in this analysis. A positive value is demonstrated by the higher value of the Tstatistic than the T-table value of 1.96 and the original sample value, which indicates that Organizational Citizenship Activity (OCB) has a positive and important influence on employee performance. This occurs because staff always follows the rules and represents the company. This can be seen from the discipline of employees, the commitment of employees to the firm, and the emphasis on their jobs. It encourages workers to build a positive attitude of Organizational Citizenship Behavior (OCB) that impacts the success of employees. This research indicates that organizations with good workers would be better than others if they can build good Corporate Citizenship Actions (OCB). Organizational Citizenship Behavior (OCB) has a positive and important influence on employee success, confirming the findings of this hypothesis [10][4].

\section{Conclusion}

Based on the analysis results, it can be concluded that emotional intelligence has a significant role and can affect the attitudes and behavior of employees at PT ISS Jakarta Barat. A significant influence on employee work stress and a positive effect on employee Organizational Citizenship Behavior (OCB). Meanwhile, the effect of the employee's performance is also positive. Thus, these results indicate that it is essential to maintain employee emotional intelligence so that the company's attitudes and behavior can be better. With a high level of stress, it will be tough for a company to improve its employees' performance. Companies must be able to influence employees by using the role of emotional intelligence.

It is better if leaders give appropriate time to their employees to complete their work; leaders should be able to recognize the emotions that are happening to employees so that they can help control these emotions. Leaders and employees should create harmony conditions and mutual respect between employees and leaders to create good Organizational Citizenship Behavior (OCB) in the company. It is better if employees also have the ability to minimize boredom and conflict. In order not to create employees' complaints and problems. Suggestions for future researchers, it is better if further researchers can add variables that have not been used in this study, such as job satisfaction, organizational culture, leadership style, organizational commitment, and so on.

\section{References}

[1] "titisari, 2014.pdf.".

[2] I. Hutagalung, "Pengaruh Kecerdasan Emosional, Komunikasi Interpersonal, Komitmen Organisasi terhadap Manajemen Stres Kerja," Pengaruh Kecerdasan Emosional, Komun. Interpersonal, Komitmen Organ. terhadap Manaj. Stres Kerja, vol. 3, no. 2, pp. 103-111, 2014.

[3] J. M. Antony, "the Influence of Emotional Intelligence on Organizational Commitment and Organizational Citizenship Behavior,” J. Soc. Sci. Res., vol. 1, no. 1, pp. 5-8, 2013.

[4] T. Fitriastuti, "No Title," J. Din. Manaj., vol. 4, no. 2, pp. 103-114, 2013.

[5] S. and M. A. Zamir, "No Title," Elixir Int. J., vol. 40, pp. 5357-5362, 2011.

[6] A. and G. S. Tziner, "Organizational Citizenship Behavior, Organizational Justice, Job Stress, and Work Familly Conflict: Examination of Their Interrelationships with Respondents from a NonWestern Culture," J. Work Organ. Psychol., vol. 30, no. 1, pp. 35-42, 2014.

[7] A. Yahaya, N. Yahaya, H. Maalip, and J. Ramli, "The relationship between the occupational stress, organizational commitment, and job satisfaction with organizational citizenship behavior.," Arch. Des 
Sci., vol. 65 , no. 4 , pp. 55-73, 2012.

[8] A. Ahmed, "Effects of Job Stress on Employees Job Performance A Study on Banking Sector of Pakistan,” IOSR J. Bus. Manag., vol. 11, no. 6, pp. 61-68, 2013.

[9] J. Y. Roboth, "Analisis Work Family Conflict, Stres Kerja dan Kinerja Wanita Berperan Ganda pada Yayasan Compassion East Indonesia," J. Ris. Bisnis dan Manaj., vol. 3, no. 1, pp. 33-46, 2015.

[10] D. N. Soepono and V. A. Srimulyani, "Analisis Pengaruh the Big Five Personality Terhadap Organizational Citizenship Behavior (Ocb) Dan Kinerja Perawat Di Rs Santa Clara Madiun,” J. Manaj. Indones., vol. 15, no. 1, p. 51, 2017.

[11] D. Goleman, Emotional Intelligence: Mengapa EI LebihPentingdaripada IQ. 2015.

[12] Robbins and Jugde, No Title. 2015.

[13] D. H. Wibowo, Z. Arifin, and . Sunarti, "Analisis Strategi Pemasaran Untuk Meningkatkan Daya Saing UMKM (Studi pada Batik Diajeng Solo),” J. Adm. Bisnis, vol. 29, no. 1, pp. 59-66, 2015.

[14] "Zainal, 2014 Manajemen Sumber Daya Manusia Untuk Perusahaan Dari Teori Ke Praktik." .

[15] A. Mangkunegara, No Title. 2006.

[16] A. Mangkunegara, No Title. 2010.

[17] F. F. Hotiana N, "Pengaruh Motivasi dan Stres Kerja terhadap Kinerja Pegawai," J. Ris. Manaj. dan Bisnis, vol. 3, no. 1, pp. 27-36, 2018.

[18] wilson Bangun, No Title. 2012.

[19] A. M. Saleem WA, "Person Organization Fit, Organizational Commitment and Knowledge Sharing Attitudeâ€“An Analytical Study,” Inf. Manag. Bus. Rev., vol. 3, no. 2, p. 110, 2011.

[20] Sugiyono, Metode Penelitian Bisnis. Alfabetha, Bandung, 2013.

[21] Ghozali, Imam, No Title. 2015

[22] M. Subagio, "Pengaruh Kecerdasan Emosional, Motivasi Kerja, Dan Sikap Kerja Terhadap Kinerja Karyawan Pada Pt Ithaca Resources,” J. Manaj., vol. 19, no. 1, p. 101, 2017. 